University of Nebraska - Lincoln

DigitalCommons@University of Nebraska - Lincoln

USDA National Wildlife Research Center - Staff Publications
U.S. Department of Agriculture: Animal and Plant Health Inspection Service

$1-2012$

\title{
Airports Offer Unrealized Potential for Alternative Energy Production
}

Travis L. DeVault

USDA/APHIS/WS National Wildlife Research Center, Travis.L.DeVault@aphis.usda.gov

Jerrold L. Belant

Mississippi State University, jbelant@cfr.msstate.edu

Bradley F. Blackwell

United States Department of Agriculture, bradley.f.blackwell@aphis.usda.gov

James A. Martin

Mississippi State University, jmartin@cfr.msstate.edu

Jason A. Schmidt

United States Department of Agriculture, jason.a.schmidt@aphis.usda.gov

See next page for additional authors

Follow this and additional works at: https://digitalcommons.unl.edu/icwdm_usdanwrc

DeVault, Travis L.; Belant, Jerrold L.; Blackwell, Bradley F.; Martin, James A.; Schmidt, Jason A.; Burger, Loren Wes Jr; and Patterson, James W. Jr., "Airports Offer Unrealized Potential for Alternative Energy Production" (2012). USDA National Wildlife Research Center - Staff Publications. 1121.

https://digitalcommons.unl.edu/icwdm_usdanwrc/1121

This Article is brought to you for free and open access by the U.S. Department of Agriculture: Animal and Plant Health Inspection Service at DigitalCommons@University of Nebraska - Lincoln. It has been accepted for inclusion in USDA National Wildlife Research Center - Staff Publications by an authorized administrator of DigitalCommons@University of Nebraska - Lincoln. 


\section{Authors}

Travis L. DeVault, Jerrold L. Belant, Bradley F. Blackwell, James A. Martin, Jason A. Schmidt, Loren Wes Burger Jr, and James W. Patterson Jr. 


\title{
Airports Offer Unrealized Potential for Alternative Energy Production
}

\author{
Travis L. DeVault $\cdot$ Jerrold L. Belant $\cdot$ Bradley F. Blackwell • \\ James A. Martin · Jason A. Schmidt • L. Wes Burger Jr • \\ James W. Patterson Jr
}

Received: 30 March 2011 / Accepted: 9 December 2011/Published online: 14 January 2012

(C) Springer Science+Business Media, LLC (outside the USA) 2012

\begin{abstract}
Scaling up for alternative energy such as solar, wind, and biofuel raises a number of environmental issues, notably changes in land use and adverse effects on wildlife. Airports offer one of the few land uses where reductions in wildlife abundance and habitat quality are necessary and socially acceptable, due to risk of wildlife collisions with aircraft. There are several uncertainties and limitations to establishing alternative energy production at airports, such as ensuring these facilities do not create wildlife attractants or other hazards. However, with careful planning, locating alternative energy projects at airports could help mitigate many of the challenges currently facing policy makers, developers, and conservationists.
\end{abstract}

Keywords Airport · Biofuel · Energy · GIS ·

Grassland $\cdot$ Solar $\cdot$ Wildlife $\cdot$ Wind

Rapidly increasing global energy needs and domestic policy objectives promoting energy independence demand innovative renewable energy solutions. Accelerated development of

T. L. DeVault $(\bowtie)$ · B. F. Blackwell · J. A. Schmidt United States Department of Agriculture, Wildlife Services, National Wildlife Research Center, Sandusky, OH 44846, USA e-mail: Travis.L.DeVault@aphis.usda.gov

J. L. Belant · J. A. Martin - L. Wes Burger Jr Department of Wildlife, Fisheries, and Aquaculture, Mississippi State University, Mississippi, MS 39762, USA

J. W. Patterson Jr

United States Federal Aviation Administration,

William J. Hughes Technical Center, Atlantic City,

NJ 08405, USA energy sources including solar and wind has generated numerous conservation concerns, especially when locating new facilities (Cho 2010; Kintisch 2010). Additionally, increased biofuel production has exacerbated land clearing in many areas worldwide (Fargione and others 2008, 2010; Groom and others 2008; Somerville and others 2010). Land conversion of natural communities to biofuel production, solar panel arrays, and wind-power installations, as well as direct mortality of birds and bats from wind turbines (Curry 2009; Kintisch 2010), often necessitate mitigation to minimize adverse environmental impacts (Fargione and others 2008; Curry 2009).

Ostensibly, ideal locations for alternative energy production would contain large expanses of idle land, harbor relatively little wildlife (i.e., vertebrates), be mostly unsuitable for conservation initiatives, and not compete with human food production. Campbell and others (2008) advocated the use of degraded and abandoned agricultural land for bioenergy production, demonstrating that such areas could produce a meaningful proportion of global energy demand. Here, we highlight the potential for alternative energy production at airports, another common and extensive form of land use worldwide that is unsuitable for many other purposes.

Airports offer one of the few land holdings where reductions in wildlife abundance and habitat quality are necessary and socially acceptable, and where regulations discourage traditional commodity production (International Civil Aviation Organization 2002; Federal Aviation Administration 2007). Specifically, wildlife use of lands in and adjacent to airports often presents unacceptable risks to human safety (Blackwell and others 2009; Marra and others 2009). Annual economic losses from wildlife collisions with civil aircraft are conservatively estimated to exceed US\$1.2 billion worldwide (Allan 2002) and US\$600 million in the U.S. alone (Dolbeer and others 2009). Further, from 1912 through 
2008, 108 civil aircraft were destroyed due to bird strikes, and 54 bird strikes to civil aircraft resulted in 276 human deaths (Thorpe 2010). To minimize wildlife-aviation collision risk, most civil airports in the U.S. that receive regular passenger traffic maintain programs to reduce wildlife use and habitat suitability on airports (Dolbeer and others 2009).

There are 44,010 airports in the world and 15,079 in the U.S. (Central Intelligence Agency [CIA] 2010), and many of these manage substantial areas of land for safety, noise abatement, and security purposes. To evaluate the potential for such areas to support development of alternative energy, we estimated the amount of grasslands-an index of idle land-within airports in the contiguous U.S. included in the National Plan of Integrated Airport Systems ( $n=2915$; Appendix). These airport properties contain an estimated $3306 \mathrm{~km}^{2}$ of grasslands, an area larger than the U.S. state of Rhode Island (Table 1). When considering the $3-\mathrm{km}$ separation distance between the air operations areas for certificated airports and land uses (e.g., putrescible waste disposal operations, waste water treatment plants, public parks) designated as potentially attracting species recognized as hazardous to aviation (Dolbeer and others 2000, 2009; Federal Aviation Administration 2007), estimated grassland area increases about three-fold. Because airports tend to be located in rural areas on the fringes of urban development, much of the land within the separations distances might be suitable for alternative energy production.

Potential suitability of alternative energy practices varies markedly across the contiguous U.S. (Fig. 1). However, most airports appear regionally suitable for development of at least one major renewable energy source. Reflecting recent initiatives to increase environmental stewardship at airports (McAllister 2009), the U.S. Federal Aviation Administration is currently researching issues related to the establishment of solar and wind facilities at airports (Infanger 2010), and recently published detailed guidance for installation of solar facilities (Federal Aviation Administration 2010a).

Table 1 Estimated grassland area at airports in the contiguous U.S. See Appendix for methods

\begin{tabular}{lrlll}
\hline $\begin{array}{l}\text { Airport } \\
\text { classification }\end{array}$ & $n$ & $\begin{array}{l}\text { Mean airport } \\
\text { property area } \\
\text { (ha) }\end{array}$ & $\begin{array}{l}\text { Percent of } \\
\text { airport property } \\
\text { in grassland }\end{array}$ & $\begin{array}{l}\text { Total } \\
\text { grassland } \\
\text { area }\left(\mathrm{km}^{2}\right)\end{array}$ \\
\hline $\begin{array}{l}\text { Certificated } \\
\begin{array}{l}\text { General } \\
\text { aviation }\end{array}\end{array}$ & 521 & 761 & 39 & 1546 \\
Total & 2394 & 147 & 50 & 1760 \\
\hline
\end{tabular}

Airport areas and number of airports were obtained from the U.S. Federal Aviation Administration; http://www.faa.gov/airports/ airport_safety/airportdata_5010/
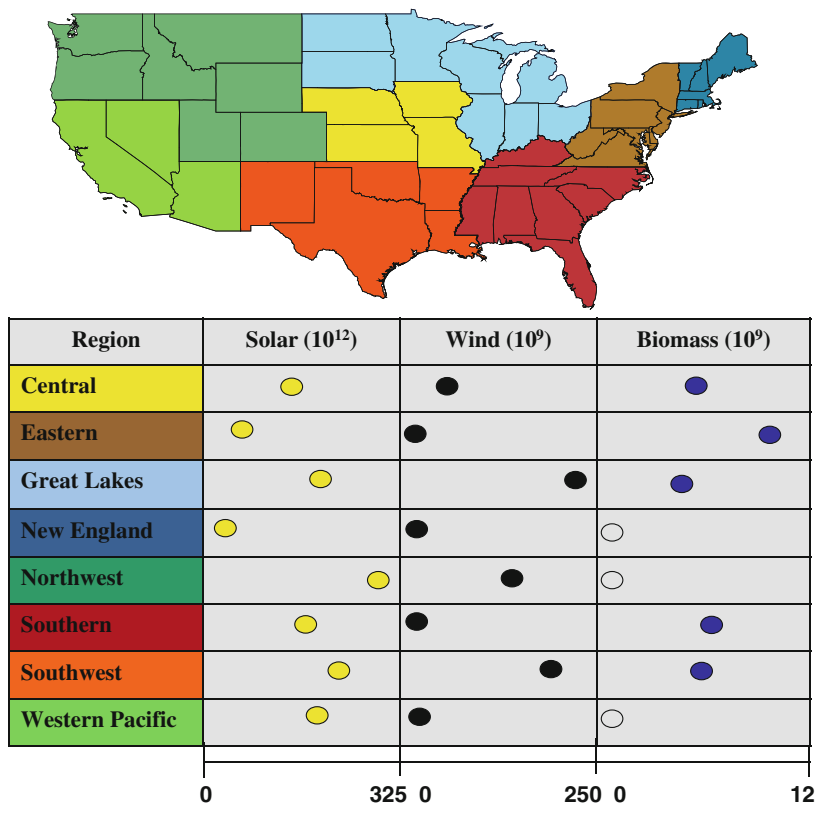

Fig. 1 Alternative energy potential for Federal Aviation Administration (FAA) management regions in the contiguous U.S. Values represent the average BTU/ $\mathrm{km}^{2}$ potentially produced by three energy sources: solar, wind, and an herbaceous perennial-switchgrass (Panicum virgatum L.). Regions with open circles for biomass lack empirical data. We provide a coarse index of the potential suitability of each FAA management region for solar, wind, and switchgrass biofuel energy. Our goal was to illustrate that most regions have potential to produce at least one type of alternative energy; we recognize other factors (e.g., site-specific conditions, access to processing technology, etc.) will influence the economic feasibility of alternative energy production on airports. We estimated solar and wind energy potential using national datasets from the National Renewable Energy Laboratory (http://www.nrel.gov), operated by the Alliance for Sustainable Energy, LLC, for the U.S. Department of Energy. We used an online database housed at the Oak Ridge National Laboratory (ORNL) (http://bioenergy.ornl.gov/main. aspx\#Perennial\%20Grasses) to estimate average switchgrass production rates. Conversion factors for energy content were based on ORNL's energy conversion reference list (http://bioenergy.ornl. gov/papers/misc/energy_conv.html). For example, $900 \mathrm{Mg} / \mathrm{km}^{2}$ of switchgrass containing $378 \mathrm{l}$ ethanol/Mg yields $340,650 \mathrm{l} / \mathrm{km}^{2}$. We used a GIS to compile data by FAA region; however, switchgrass production data were lacking for the New England, Northwest, and Western-Pacific regions. We excluded these regions from analysis and assumed they have limited potential for switchgrass production based on predicted estimates (Wullschleger and others 2010)

Several airports have already implemented solar, and to a much lesser extent, wind technology to offset energy demands of these facilities (Baskas 2009; Infanger 2010; Sinha 2010; Federal Aviation Administration 2010a). For example, at Fresno Yosemite International Airport, California, U.S., the city of Fresno constructed a $2.4 \mathrm{MW}$ photovoltaic array in 2008 (Federal Aviation Administration 2010a). Despite occupying only about 6.5 ha $(<1 \%$ of total airport property), the facility produces enough energy to meet about $60 \%$ of the airport's annual energy demand, 
and during winter produces surplus energy that is sold to the energy grid provider (K. Meikle, Airports Planning Manager, City of Fresno, pers. comm.). Airport projections estimate the facility will provide >US\$19 million in energy cost savings over 20 years. Similarly, Meadows Field in Bakersfield, California, U.S., leases a $744 \mathrm{~kW}$ photovoltaic array from a private developer. The array, which covers 2.4 ha $(<0.5 \%$ of total airport property), produces about $75 \%$ of the airport's annual energy demand (Federal Aviation Administration 2010a). Like the solar array at Fresno, the facility at Meadows Field is connected to the local energy grid. Thus, the airport is able to sell energy to the grid provider during peak generation hours when energy produced exceeds demand at the airport (Federal Aviation Administration 2010a). At Denver International Airport (DEN) in Colorado, U.S., one of the nation's busiest airports, two photovoltaic solar arrays (2.0 and 1.6 MW) have been commissioned since 2008 (Federal Aviation Administration 2010a). Together, they occupy $\sim 7.5$ ha $(<0.05 \%$ of total airport property) and produce about 3\% of DEN's annual energy demand (E. Keegan, Senior Engineer, DEN, pers. comm.). A third solar facility, rated at $4.5 \mathrm{MW}$, is currently under construction at DEN. Given the small size of these solar facilities relative to available idle land at many airports, expanding this technology across grasslands could further meet energy needs and in some cases create substantial surpluses to be sold offsite. As demonstrated by extant facilities at Fresno and Bakersfield, moving electricity to energy grids is simplified because many airports are located adjacent to urban centers.

Although there appears to be momentum for the establishment of wind and especially solar facilities at airports, we are unaware of any biofuel production sites at U.S. airports. Undoubtedly, the lack of biofuel agriculture reflects, in part, Federal Aviation Administration regulations discouraging the presence of "hazardous wildlife attractants", including all types of agriculture, on and near certificated U.S. airports (Federal Aviation Administration 2007; Blackwell and others 2009). However, in practice many U.S. airports lease portions of their land for agricultural production (Blackwell and others 2009; DeVault and others 2009). These crops often include corn (Zea mays) and wheat (Triticum spp.), which are known wildlife attractants (Cerkal and others 2009). In fact, additional guidelines to U.S. airports, though seemingly conflicting with the aforementioned recommendations, provide minimum distances from runways and aprons for on-airport agricultural crops relative to size of aircraft serviced (Federal Aviation Administration 1989). These minimum distances would also apply to biofuel production. Also, traditional turfgrass management commonly employed at airports up to runway edges often attracts species hazardous to aviation, including Canada geese (Branta canadensis), ring-billed gulls (Larus delawarensis), and European starlings (Sturnus vulgaris; Martin and others 2011). Clearly, a range of vegetation types already occur on and adjacent to airports. The suitability of each vegetation type for use at airports should not be based on overall wildlife species use, but on the relative hazards these species pose to aircraft (DeVault and others 2011). A vegetation type attracting greater wildlife abundance and biodiversity may actually represent a lower hazard to aircraft and be more suitable for use at airports. We are aware of no studies that have quantified wildlife response to various vegetation types and associated risks to aviation.

Existing grasslands at airports potentially could be managed for biofuel production (Blackwell and others 2009) if converted to appropriate cellulosic feedstocks. Switchgrass, for instance, can yield $8.7-12.9 \mathrm{Mg} / \mathrm{ha}$ depending on ecotype (Wullschleger and others 2010). More specifically, using Indiana, U.S., as an example, an airport with 205 ha of grassland (the median size of grasslands at certificated airports in the U.S.; see below) could produce $2977 \mathrm{Mg} \mathrm{ha}^{-1}$ annually (Casler 2005), and if converted to fuel would produce $1.13 \times 10^{6} 1$ of ethanol. Low-input, diverse, native warm-season grass mixtures may produce even higher ethanol yields with greater greenhouse gas benefits (Tilman and others 2006). The economic profitability of these systems will vary markedly, but will be contingent primarily on yield, establishment and maintenance costs, opportunity costs of land (i.e., land rental or revenue from other commodities), and processing costs (Jain and others 2010). Unlike typical agriculture production scenarios, opportunity costs for the airport setting will be much less given the current non-revenue producing land use typical of many airport grasslands.

Although use of grasslands managed for biofuel production by species hazardous to aviation could affect safety, candidate crops for biofuel production range widely, from monocultures of exotic plants [e.g., miscanthus (Miscanthus giganteus)] to diverse native warm-season grass mixtures (Tilman and others 2009; Somerville and others 2010). Consequently, species composition of wildlife communities varies widely across different biofuel crops (Fargione and others 2009; Meehan and others 2010; Robertson and others 2010). Field research likely could identify productive biofuel crops that, from a wildlife perspective, are compatible with safe airport operations (Blackwell and others 2009; DeVault and others 2011; Martin and others 2011).

Tilman and others (2006) estimated that biomass from low-input high-diversity mixtures of native grassland perennials converted to gasoline and diesel synfuels would yield 51\% more usable energy/ha from degraded infertile land than grain production for ethanol from fertile soils. 
The authors based their calculations, in part, on assumptions regarding costs associated with production from lands on a 240-ha U.S. family farm, an area less than the average area of grassland present on certificated U.S. airports (Table 1). We recognize the amount of grassland available on individual airports is, alone, far less than the area necessary to sustain a biofuel energy plant (Kocoloski and others 2011); however, airports could be integrated into an overall regional production and transportation strategy for biofuel production. For example, we compared the median grassland area at certificated airports in the U.S. (205 ha) to the median farm size from each U.S. state and found that only $10 \%$ of states had median farm sizes larger than airport grasslands (U.S. Department of Agriculture 2009). This suggests that airport grasslands, in size alone, could contribute to the land base needed to supply energy plants. In areas where production of cellulosic biofuel stock is currently unprofitable, many such crops (e.g., switchgrass and other native grass perennials) potentially could be produced for livestock forage with minimal changes to harvest regimens (Sarath and others 2008) until biofuel production facilities are more widespread. Regardless, mowing at airports is expensive ( $\sim$ US $\$ 10 /$ ha for each mowing; Washburn and Seamans 2007), and even marginally profitable crops could be economically preferable to current turfgrass management.

Factors other than wildlife use also should be considered before wide-scale development of alternative energy sources at airports. We note, for example, that minimumdistance categories to on-airport agricultural crops are components of guidelines that address pilot line-of-sight within the air operations area, and measures to ensure obstruction-free movement of aircraft on aprons, taxiways, and runways, as well as access for emergency response (see Federal Aviation Administration 1989). Thus, some grassland areas on airports, such as those immediately adjacent to air-operations areas, likely will not be suitable for conversion to biofuel or other alternative energy production because of conflicts with established safety regulations (see also Blackwell and others 2009 for a more detailed discussion of land use and safety regulations at airports).

Further, wind turbine height in relation to aircraft movements (Federal Aviation Administration 2000) and turbine effects on radar (Kintisch 2010) pose safety concerns. Although the heights of most modern wind turbines will preclude their placement near air operations areas, establishment of wind turbines at some larger airports might be feasible (e.g., DEN, although an outlier in size among U.S. airports, covers 13,540 ha). Also, though wind turbines can interfere with both airborne and ground-based radar, the U.S. Federal Aviation Administration is currently researching potential solutions, including development of turbines that are undetectable by radar, and use of small radar sensors placed at turbines that provide localized coverage and transmit data to primary radar systems (Infanger 2010; Kintisch 2010).

Regarding solar technology, there was early concern that reflection (i.e., glare) from solar arrays could be problematic for pilots. However, because photovoltaic panels (which are thought to be more suitable for airport use than concentrated solar power; Federal Aviation Administration 2010a) are designed to absorb rather than reflect energy, such concerns have largely proven unfounded (Federal Aviation Administration 2010a; Infanger 2010). Also, placement of these arrays on U.S. airports is in adherence to established guidelines for structures within the air operations areas (Federal Aviation Administration 1989), which consider potential effects on pilot line-ofsight and obstruction hazards. Some airports have avoided siting problems by using existing rooftops for solar installations (Federal Aviation Administration 2010a). Furthermore, although existing solar facilities at airports do not appear to serve as attractants to wildlife species recognized as hazardous to aviation (Dolbeer and others 2000, 2009), no formal studies have been completed (Federal Aviation Administration 2010a), though this research is now underway (TLD, "unpublished data"). Such information will be useful as more airports consider construction of solar facilities in coming years.

Grassland management at airports typically involves periodic mowing for safety and security reasons at an economic and environmental cost. Further, the dynamics of wildlife (particularly bird) use of airport grasslands relative to mowing regimens is speculative at best (Blackwell and others 2009). With thoughtful planning regarding the uncertainties and limitations associated with the establishment of alternative energy production at airports discussed above, converting airport grasslands to these land uses could maintain existing benefits and provide increased revenue, reductions of hazardous wildlife, and more environmentally-sound alternative energy. There is no single answer for meeting global energy demands or addressing environmental consequences of energy development (Turner 1999; Curry 2009; Cho 2010; Kintisch 2010). To bring us one step closer to a solution, we should explore alternative-energy practices and land-use patterns at airports to identify useful options and develop effective and integrated energy, wildlife, and air-safety policies.

Acknowledgments The United States Department of Agriculture, Mississippi State University, and the U.S. Federal Aviation Administration support our research. We thank P. M. Schmidt, R. King, and L. Clark for providing comments on the manuscript, and E. Poggiali for administrative support. 


\section{Appendix: Methods Used to Estimate Grassland Area at Airports in the Contiguous U.S.}

Although there are 15,079 airports in the U.S. (5,174 with paved runways) (Central Intelligence Agency [CIA] 2010), we limited our estimates of grassland area to the 2,915 airports in the contiguous U.S. considered significant to national air transportation and thus included in the National Plan of Integrated Airport Systems (NPIAS). In general there are two types of airports included in NPIAS: "certificated" airports are those approved by the U.S. Federal Aviation Administration (FAA) for regularly scheduled ( $>9$ seats) or unscheduled ( $>30$ seats) passenger traffic; the remaining, smaller airports are categorized as 'general aviation' (GA) airports (Blackwell and others 2009). Because certificated and GA airports differ substantially in size, landcover composition, and types of wildlife hazards (Dolbeer and others 2008; Federal Aviation Administration 2010b), we generated separate estimates of grassland area within airport properties for each. Also, for certificated airports we estimated grassland area within $3 \mathrm{~km}$ of air operations areas (AOA; runways and taxiways). Sixty-six percent of wildlife strikes that cause substantial damage to aircraft occur within $3 \mathrm{~km}$ of the AOA (Dolbeer 2006; Blackwell and others 2009), and the FAA discourages placement of wildlife attractants within that distance at airports servicing turbine-powered aircraft (Federal Aviation Administration 2007).

For certificated airports, we used a Geographic Information System (GIS) to estimate the extent of grasslands at a sample of 49 airports. We randomly selected $10 \%$ of certificated airports located within each of eight Omernik Level I ecological regions (Omernik 1987) in the contiguous U.S. Two ecological regions were excluded because of their small size ( 0.28 and $0.55 \%$ of the contiguous U.S.) and scarcity of certificated airports. We used the GIS to extract grassland polygons from 2007-2009 true-color digital orthoimagery with $1-\mathrm{m}$ resolution obtained from the National Agriculture Imagery Program (NAIP). We defined grassland as any land occupied by native or exotic grasses, including hayfields and rangeland but excluding row crops. For our extraction protocol, we used all three available spectral bands, a resample factor of two, a Manhattan 7 input representation, a minimum object size of 25 pixels, and included instances of rotated features.

We assessed the accuracy of our grassland extractions by placing 100 random points on each of four airport classification maps, split evenly between grassland and non-grassland cover types, and then determined whether points were classified correctly. Overall accuracy was $85 \%$ (339 of 400 points were classified correctly). The kappa coefficient, a measure of agreement between the extraction classification and the reference data, was 0.7 , indicating substantial agreement (Landis and Koch 1977). The producer's accuracy (probability of a reference point being correctly classified) was 90 and $81 \%$ for grassland and nongrassland cover types, respectively; the user's accuracy (probability that a point classified in the extraction represents the correct landcover type) was 78 and $92 \%$ for grassland and non-grassland cover types, respectively. Finally, we processed 2003 true-color digital orthoimagery (spatial resolution of $1 \mathrm{~m}$; also from NAIP) for 10 small airports (nine GA and one small certificated airport) in Indiana, U.S. using our extraction protocol, and compared our results with landcover classifications made by manual digitization and on-site ground truthing (DeVault and others 2009). A Wilcoxon signed rank test (Statistix 2008) indicated no difference $(P=0.103)$ between the two landcover classification methods for grasslands, suggesting our extraction protocol was accurate. GIS analyses were conducted using ArcMap ver. 9.3 (Environmental Systems Research Institute, Redlands, California, U.S.), Feature Analyst for ArcGIS ver. 4.2, and Hawth's Analysis Tools ver. 3.27.

Across our sample of certificated airports, we calculated a mean of $39 \pm 16 \%$ (SD) grassland cover within each airport property (Table 1), and a mean of $16 \pm 9 \%$ within $3 \mathrm{~km}$ of the AOA. Totaled across all certificated airports in the contiguous U.S., we estimated about $1,546 \mathrm{~km}^{2}$ of grassland within airport properties, and an additional $4,460 \mathrm{~km}^{2}$ within $3 \mathrm{~km}$ of the AOA.

To estimate the amount of grassland area at GA airports, we examined GIS landcover classifications conducted by DeVault and others (2009) for small airports in Indiana, U.S. DeVault and others (2009) reported that about $56 \%$ of the land cover within airport properties was composed of grassland. Using a conservative estimate of $50 \%$ grassland area, we estimated approximately $1,760 \mathrm{~km}^{2}$ of grassland on GA airport properties in the contiguous U.S. (Table 1). In total, we estimated there are approximately $3,306 \mathrm{~km}^{2}$ of grassland within airport properties in the contiguous U.S. Considering that there are about 12,000 small airports in the U.S. not included in NPIAS and thus not included in our calculations, plus military airfields, our estimate of grassland area is likely very conservative.

\section{References}

Allan JR (2002) The costs of bird strikes and bird strike prevention. In: Clark L (ed) Proceedings of the National Wildlife Research Center Symposium, Human Conflicts with Wildlife: Economic Considerations. Department of Agriculture, National Wildlife Research Center, Fort Collins, pp 147-155

Baskas H (2009) Solar-powered airports? It could happen. USA Today, 28 Apr 2009 
Blackwell BF, DeVault TL, Fernandez-Juricic E, Dolbeer RA (2009) Wildlife collisions with aircraft: a missing component of landuse planning for airports. Landscape and Urban Planning 93:1-9

Campbell JE, Lobell DB, Genova RC, Field CB (2008) The global potential of bioenergy on abandoned agricultural lands. Environmental Science and Technology 42:5791-5794

Casler MD (2005) Ecotypic variation among switchgrass populations from the northern USA. Crop Science 45:388-398

Central Intelligence Agency [CIA] (2010) The world factbook. Accessed online September 8, 2010. https://www.cia.gov/library/ publications/the-world-factbook/geos/us.html

Cerkal R, Vejražka K, Kamler J, Dvořák J (2009) Game browse and its impact on selected grain crops. Plant, Soil and Environment 55:181-186

Cho A (2010) Energy's tricky tradeofffs. Science 329:786-787

Curry A (2009) Deadly flights. Science 325:386-387

DeVault TL, Kubel JE, Rhodes OE Jr, Dolbeer RA (2009) Habitat and bird communities at small airports in the midwestern USA. Proceedings of the Wildlife Damage Management Conference 13:137-145

DeVault TL, Belant JL, Blackwell BF, Seamans TW (2011) Interspecific variation in wildlife hazards to aircraft: implications for airport management. Wildlife Society Bulletin 35(4): 394-402

Dolbeer RA (2006) Height distribution of birds recorded by collisions with civil aircraft. Journal of Wildlife Management 70: $1345-1350$

Dolbeer RA, Wright SE, Cleary EC (2000) Ranking the hazard level of wildlife species to aviation. Wildlife Society Bulletin 28: 372-378

Dolbeer RA, Begier MJ, Wright SE (2008) Animal ambush: the challenge of managing wildlife hazards at general aviation airports. Proceedings of the Corporate Aviation Safety Seminar 53:1-17

Dolbeer RA, Wright SE, Weller J, Begier MJ (2009) Wildlife strikes to civil aircraft in the United States 1990-2009. Federal Aviation Administration Serial Report No. 15

Fargione J, Hill J, Tilman D, Polasky S, Hawthorne P (2008) Land clearing and the biofuel carbon debt. Science 319:1235-1238

Fargione JE, Cooper TR, Flaspohler DJ, Hill J, Lehman C, McCoy T, McLeod S, Nelson EJ, Oberhauser KS, Tilman D (2009) Bioenergy and wildlife: threats and opportunities for grassland conservation. BioScience 59:767-777

Fargione JE, Plevin RJ, Hill JD (2010) The ecological impact of biofuels. Annual Review of Ecology, Evolution, and Systematics 41:351-357

Federal Aviation Administration (1989) Airport design. Advisory Circular 150/5300-13, Appendix 17, Washington

Federal Aviation Administration (2000) Proposed construction or alteration of objects that could affect navigable airspace. Advisory Circular 70/7460, Washington

Federal Aviation Administration (2007) Hazardous wildlife attractants on or near airports. Advisory Circular 150/5200-33B, Washington

Federal Aviation Administration (2010a) Technical guidance for evaluating selected solar technologies on airports. Federal Aviation Administration Report FAA-ARP-TR-10-1, Washington

Federal Aviation Administration (2010b) Airport Data \& Contact Information. Accessed online September 8, 2010. http://www. faa.gov/airports/airport_safety/airportdata_5010/

Groom MJ, Gray EM, Townsend PA (2008) Biofuels and biodiversity: principles for creating better policies for biofuel production. Conservation Biology 22:602-609

Infanger JF (2010) The pros, cons of solar, wind. Airport Business 24(9):18-19
International Civil Aviation Organization (2002) Land use and environmental control. Airport Planning Manual 9184 AN/902, Part 2, New York

Jain AK, Khanna M, Erickson M, Huang H (2010) An integrated biogeochemical and economic analysis of bioenergy crops in the Midwestern United States. GCB Bioenergy 2:217-234

Kintisch E (2010) Out of site. Science 329:788-789

Kocoloski K, Griffin WM, Matthews HC (2011) Impacts of facility size and location decisions on ethanol production cost. Energy Policy 39:47-56

Landis JR, Koch GG (1977) The measurement of observer agreement for categorical data. Biometrics 33:159-174

Marra PP, Dove CJ, Dolbeer RA, Dahlan NF, Heacker M, Whatton JF, Diggs NE, France C, Henkes GA (2009) Migratory Canada geese cause crash of US airways flight 1549. Frontiers in Ecology and the Environment 7:297-301

Martin JA, Belant JL, DeVault TL, Burger LW Jr, Blackwell BF, Riffell SK, Wang G (2011) Wildlife risk to aviation: a multiscale issue requires a multi-scale solution. Human-Wildlife Interactions 5:198-203

McAllister B (2009) The greener, the better. Airport Business 23(8): 13-15

Meehan TD, Hurlbert AH, Gratton C (2010) Bird communities in future bioenergy landscapes of the Upper Midwest. Proceedings of the National Academy of Sciences USA 107:18745-18746

Omernik JM (1987) Ecoregions of the conterminous United States. Map (scale 1:7,500,0000). Annals of the Association of American Geographers 77:118-125

Robertson BA, Doran PJ, Loomis LR, Robertson JR, Schemske DW (2010) Perennial biomass feedstocks enhance avian diversity. GCB Bioenergy 3:235-246

Sarath G, Mitchell RB, Sattler SE, Funnell D, Pedersen JF, Graybosch RA, Vogel KP (2008) Opportunities and roadblocks in utilizing forages and small grains for liquid fuels. Journal of Industrial Microbiology Biotechnology 35:343-354

Sinha S (2010) Leh airport ACs to run on solar power. The Times of India, 4 June

Somerville C, Youngs H, Taylor C, Davis SC, Long SP (2010) Feedstocks for lignocellulosic biofuels. Science 329:790-792

Statistix (2008) Statistix 9 User's Manual. Analytical Software. Tallahassee, $\mathrm{p} 454$

Thorpe J (2010) Update on fatalities and destroyed civil aircraft due to bird strikes with appendix for 2008 \& 2009. Proceedings of the $29^{\text {th }}$ International Bird Strike Committee Meeting, Cairns, pp 1-9

Tilman D, Hill J, Lehman C (2006) Carbon-negative biofuels from low-input high-diversity grassland biomass. Science 314: $1598-1600$

Tilman D, Socolow R, Foley JA, Hill J, Larson E, Lynd L, Pacala S, Reilly J, Searchinger T, Somerville C, Williams R (2009) Beneficial biofuels - the food, energy, and environment trilemma. Science 325:270-271

Turner JA (1999) A realizable renewable energy future. Science 285:687-689

U.S. Department of Agriculture (2009) Census of agriculture. National Agricultural Statistics Service, Washington

Washburn BE, Seamans TW (2007) Wildlife responses to vegetation height management in cool-season grasslands. Rangeland Ecology and Management 60:319-323

Wullschleger SD, Davis EB, Borsuk ME, Gunderson CA, Lynd LR (2010) Biomass production in switchgrass across the United States: database description and determinants of yield. Agronomy Journal 102:1158-1168 